\title{
RELATIONSHIP BETWEEN EARLY CHILDHOOD CARIES AND ADVERSE BIRTH OUTCOMES
}

\author{
Abdulla Varoneckas ${ }^{1}$, Kotryna Jasinskaité ${ }^{1}$, Asta Varašiūté2 \\ ${ }^{1}$ Lithuanian University of Health Sciences, Faculty of Odontology, Kaunas, Lithuania, \\ ${ }^{2}$ Lithuanian University of Health Sciences, Department of pediatric dentistry, Kaunas, Lithuania
}

Keywords: preterm birth, low birth weight, early childhood caries, premature infants, small for gestational age, adverse birth outcomes, perinatal complications, dental caries.

\begin{abstract}
Summary
Purpose: The aim of this review was to assess the relationship between adverse birth outcomes and early childhood caries.

Methods: Two reviewers searched different databases from February 2020.

Results: 1376 articles were shown after the initial electronic databases search. The authors identified 10 studies investigating the incidence of dental caries among children with primary dentition, covering 79284 children, with their age ranging from 0,5 to 6 years. The studies were published from 2010 to 2020 and included retrospective, cohort, case control and cross-sectional studies. Conclusion: The found scientific evidence demonstrated that children with adverse birth outcomes are more likely to experience caries than healthy children.
\end{abstract}

\section{Introduction}

According to the World Health Organization, there are an estimated 15 million babies that are born preterm each year. That means that even more than 1 out of 10 babies are born before 37 weeks of gestation [1]. The numbers are even bigger when babies with other adverse birth outcomes, such as new-borns that are small for gestational age and new-borns with low birth weight are also included [2]. Due to these complications, when exposed to extrauterine life foetuses are not fully developed and this increases the risks of both physical and mental disorders such as cerebral palsy, seizure disorders, severe mental retardation, psychosocial and behavioural disorders, hearing loss, visual impairment, and lower respiratory tract infections [3, 4]. All the previously mentioned perinatal complications can also have a direct or indirect negative impact upon new-born's oral health. Besides oral abnormalities, such as palatal defects caused by oral intubation and long-term mechanical ventilation, developmental defects of enamel, reduced dental dimensions, delayed eruption of primary and permanent dentition are reported more frequently among prematurely born children than full-term born infants $[5,6]$. When enamel and dentin developmental disorders occur, the teeth become more vulnerable and the likelihood of being damaged by cariogenic microorganisms increases $[7,8]$.

The purpose of this review was to assess the relationship between adverse birth outcomes and early childhood caries.

\section{Methodology}

A systematic review was based on the PRISMA guidelines. The protocol for the systematic review was registered in the PROSPERO (International prospective register of systematic reviews) database. Registration number: CRD42020200414. The following focused question was developed with reference to the PICOS model: Do children born with adverse birth outcomes display higher dental caries incidence in primary dentition compared to those who were born healthy? Do children born with adverse birth outcomes display higher dental caries incidence in primary dentition compared to those who were born healthy? On 17 February 2020, a systematic search in the medical literature was carried out to identify all peer-reviewed articles, reported from 2010 to 2020 , investigating the incidence of dental caries among children with primary dentition (or up to 6 years old). Combinations of keywords "preterm birth", "low birth weight", "early childhood caries", "premature infants", "small for gestational age", "adverse birth outcomes", "perinatal complications", "dental caries" were used in the following electronic bibliographic databases: MEDLINE (searched via PubMed), EMBASE (searched via ScienceDirect), System for Information on Grey Literature in Europe, The Cochrane 
Library (Cochrane Central Register of Controlled Trials) and LILACS. Additionally, the search was expanded by checking for potential articles in the references of the included articles. No language restrictions were applied if an English summary was provided. Two independent authors (K.J. and A.V.) conducted an electronic search and selected studies that seemed to have eligible titles and abstracts for the review and met the criteria. Final selection was made after assessing full-text studies. If there were any discrepancies, the third reviewer - research advisor (As.V.) would have tried to resolve the conflict. Inclusion criteria were: retrospective studies, cohort studies, case control studies, cross-sectional studies; children with primary dentition (up to 6 years old); children with adverse birth outcomes compared with born healthy; clinical diagnosis of dental caries using caries evaluation indexes verified by World Health Organization; articles published less than 10 years ago. Exclusion criteria were: systematic reviews, meta-analyses, case series, case reports; letters to the editor, case reports, in vitro studies, animal studies, experimental studies, reviews, conference abstracts, guidelines; children with permanent dentition (older than 6 years old); studies in which the diagnosis for dental caries was not performed through a clinical examination; articles older than 10 years old. A narrative summary of inclu- ded studies was made. The generated data presenting their study design, characteristics of participants, diagnostic criteria, interventions, and outcome points was put into a table.

\section{Results}

1376 articles were shown after the initial electronic database search. Removing duplicates in turn returned 1283 articles, then after screening titles for their relevance, 56 articles were chosen in this stage. 34 articles were excluded having read their abstract. After applying all the filters and reading full-text articles, 10 articles fit our inclusion criteria and were included in this systematic review. [8-17] The final sample consisted of 5 cross-sectional $[8,9,12,13,17], 4$ cohort $[14,10,15,16], 1$ case control [11] studies. Characteristics of all 10 publications included in the review are presented in Table 1 and Table 2. The articles were published between the year 2010 and 2020. Number of patients varied from 128 to 74748 (a total of 79284 patients in 10 studies) with patients age ranging from 0,5 to 6 years. All 10 studies evaluated caries with verified indexes: 3 studies dmft [9, 11, 13], 2 - dmfs [10, 12], 3- ECC [8, 16, 17], 1- dde [14]and 1- deft [15]. 8 out of 10 studies examined children that were born preterm [8-11, 14-16, 17], 2 out of 10 studies examined children that were born small for gestational age $[10,15]$ and in all the studies except one [16] low birth weight children were included. In all of the chosen studies preterm birth (PB) was defined as a birth at less than 37 weeks gestation, low birth weight (LBW) as birthweight less than $2500 \mathrm{~g}$ and small-for-gestational-age (SGA) as birthweight less than $10^{\text {th }}$ percentile of expected weight for gestational age.

Eight studies [8-11, 14-16, 17] have reported that preterm children have higher caries indexes than full term children, however the difference was statistically significant in only two of them $[16,17]$. According to nine studies, LBW children had greater caries prevalence

Table 1. Characteristics of the included studies no.1

\begin{tabular}{|c|c|c|c|c|c|}
\hline $\begin{array}{l}\text { Author, } \\
\text { year }\end{array}$ & Study design & Sample & Gender & Age & $\begin{array}{l}\text { Dental caries } \\
\text { evaluation } \\
\text { index }\end{array}$ \\
\hline $\begin{array}{l}\text { Rajshekar, } \\
2011\end{array}$ & cross-sectional & $\begin{array}{l}\text { Control group: } 250 \\
\text { PTLBW group: } 250\end{array}$ & $\begin{array}{l}\text { Control group: } 137 \text { male, } \\
113 \text { female children } \\
\text { PTLBW group: } 138 \text { male, } \\
112 \text { female children }\end{array}$ & $1-6$ years & dmft \\
\hline $\begin{array}{l}\text { Nelson, } \\
2013\end{array}$ & cohort & $\begin{array}{l}\text { Control group: } 234 \\
\text { VLBW group: } 234\end{array}$ & $\begin{array}{c}\text { Control group: } 128 \text { male, } \\
106 \text { female children } \\
\text { VLBW group: } 120 \text { male, } \\
114 \text { female children } \\
\end{array}$ & $\begin{array}{c}8-20 \\
\text { months }\end{array}$ & dde \\
\hline $\begin{array}{l}\text { Valdeci } \\
2014\end{array}$ & cross-sectional & 320 & - & $\begin{array}{c}43,2 \\
\text { months }\end{array}$ & ECC \\
\hline $\begin{array}{l}\text { Masumo, } \\
2014\end{array}$ & cross-sectional & $\begin{array}{l}\text { Control group: } 664 \\
\text { LBW group: } 86\end{array}$ & $\begin{array}{l}\text { Control group: } 338 \text { male, } \\
326 \text { female children } \\
\text { LBW group: } 43 \text { male, } 43 \\
\text { female children }\end{array}$ & $\begin{array}{c}6-36 \\
\text { months }\end{array}$ & dmft \\
\hline $\begin{array}{l}\text { Nirunsittirat, } \\
2016\end{array}$ & cohort & 544 & $\begin{array}{c}273 \text { male, } 271 \text { female } \\
\text { children }\end{array}$ & $\begin{array}{c}3,7 \text { years } \\
\mathrm{SD}=0,4\end{array}$ & dmfs \\
\hline $\begin{array}{l}\text { Bernabe, } \\
2016\end{array}$ & cross-sectional & 1102 & $\begin{array}{l}595 \text { male ,507 female } \\
\text { children }\end{array}$ & $1-4$ years & dmfs \\
\hline $\begin{array}{l}\text { Schüler, } \\
2017\end{array}$ & Fase control $=$ & $\begin{array}{l}\text { Control group: } 64, \\
\text { PT group: } 64 \text { (LBW } \\
\text { 44, VLBW 9, } \\
\text { ELBW 11) }\end{array}$ & $\begin{array}{l}\text { Control group: } 27 \text { male, } \\
37 \text { female children } \\
\text { PT group: } 27 \text { male, } 37 \\
\text { female children }\end{array}$ & $3-4$ years & dmft \\
\hline $\begin{array}{l}\text { Sridevia, } \\
2018\end{array}$ & cross-sectional & 690 & $\begin{array}{c}385 \text { male, } 305 \text { female } \\
\text { children }\end{array}$ & 3-6 years & ECC \\
\hline $\begin{array}{l}\text { Soares, } \\
2019\end{array}$ & cohort & 74748 & $\begin{array}{l}38271 \text { male, } 36477 \\
\text { female children }\end{array}$ & 3 years & deft \\
\hline $\begin{array}{l}\text { Boustedt, } \\
2020\end{array}$ & cohort & 208 & $\begin{array}{c}105 \text { male, } 103 \text { female } \\
\text { children }\end{array}$ & 5 years & ECC \\
\hline
\end{tabular}


than those with normal birth weight [8-15, 17]. In only four of those eight studies, however, statistically significant evidence was found to support a link between LBW children and caries prevalence $[8,11-13]$. Regarding the birth weight and caries prevalence, there is statistically significant inverse proportion to each other: the lower the children's weight, the higher the caries prevalence in LBW group. Rajshekar et al. studied caries incidence in PTLBW and FTNBW children, which was $48 \%$ and $38,8 \%$ respectively, and this difference was statistically significant [9]. 2 studies have found that children who were born SGA had a higher caries incidence compared with those AGA [10, 16], however Nirunsittirat et al. did not demonstrate statistically significant difference [10].

\section{Discussion}

In this systematic review, we analysed the most recent literature in order to determine whether the relationship between adverse birth outcome (LBW, PTB, SGA) and caries experience in children with primary dentition exists. Previous systematic reviews, however, have not found anything that could confirm the link between adverse birth outcomes and development of caries.

All of the studies that were examining preterm infants in our present review showed that PT children have a higher caries incidence that FT children [8-11, 14-16, 17]. Moreover, 9 studies reported that LBW children are more prone to develop caries than NBW children $[8-15,17]$. And lastly, children who were born SGA were reported to experience more caries than those AGA $[10,16]$. However, despite the results showing positive relationship between adverse birth outcomes and caries in the recent studies, there might as well be some lack of evidence due to particular reasons. Firstly, several studies included children who were 3 -year-old or even younger into the same statistics with 6 -year-olds $[9,12,17]$. This in turn, leads to a distortion of the results, since sometimes 3-year-olds do not have a

Table 2. Characteristics of the included studies no. 2

\begin{tabular}{|c|c|c|c|}
\hline Author, year & $\begin{array}{l}\text { Caries index value in } \\
\text { control group }\end{array}$ & $\begin{array}{l}\text { Caries index } \\
\text { value in adverse birth } \\
\text { outcomes group }\end{array}$ & p-value \\
\hline Rajshekar, 2011 & Dmft: FTNBW $1.1 \pm 2.2$ & Dmft: PTLBW $1.3 \pm 1.8$ & 0.30 \\
\hline Nelson, 2013 & $\begin{array}{l}\text { ECC: FTNBW } 0.04 \pm \\
0.37 \text { (at } 8 \text { mos) } \\
\text { FTNBW } 0.40 \pm 1.4 \text { (at } \\
18 \mathrm{mos})\end{array}$ & $\begin{array}{l}\text { ECC: PTVLBW } 0.03 \pm \\
0.23 \text { (at } 8 \text { mos), } \\
\text { PTVLBW } 0.36 \pm 1.2 \text { (at } \\
18 \text { mos) }\end{array}$ & $\begin{array}{l}0.7 \text { (at } 8 \mathrm{mos}) \\
0.78 \text { (at } 18 \mathrm{mos})\end{array}$ \\
\hline Yaldeci 2014 & $\begin{array}{l}\text { ECC (\%): NBW } 9.9 \\
\text { FT } 13.7\end{array}$ & $\begin{array}{l}\text { ECC (\%): LBW } 80.4 \\
\text { PT } 82.8\end{array}$ & $\begin{array}{l}<0.01 \\
0.149\end{array}$ \\
\hline Masumo, 2014 & ECC (\%): NBW 17.3 & ECC (\%): LBW 26.7 & $<0.05$ \\
\hline Nirunsittirat, 2016 & $\begin{array}{l}\text { ECC (\%): FT } 89.7 \\
\text { NBW } 88.6 \\
\text { AGA } 87.9\end{array}$ & $\begin{array}{l}\text { ECC (\%): PT } 77.4 \\
\text { LBW } 84.3 \\
\text { SGA } 92.9\end{array}$ & $\begin{array}{l}>0.05 \\
>0.05 \\
>0.05\end{array}$ \\
\hline Bernabe, 2016 & $\begin{array}{l}\text { Dmft: NBW } 0.05 \text { (at } \\
12 \text { mos), } \\
0.66 \text { (at } 24 \text { mos), } \\
1.41 \text { (at } 36 \mathrm{mos} \text { ), } \\
3.45 \text { (at } 48 \mathrm{mos} \text { ) }\end{array}$ & $\begin{array}{l}\text { Denft: LBW } 0.02 \text { (at } 12 \mathrm{mos} \text { ), } \\
1.31 \text { (at } 24 \text { mos), } \\
1.85 \text { (at } 36 \mathrm{mos} \text { ), } \\
5.58 \text { (at } 48 \mathrm{mos} \text { ) }\end{array}$ & $\begin{array}{l}>0.05 \\
>0.05 \\
>0.05 \\
0.044\end{array}$ \\
\hline Schüler, 2017 & $\operatorname{Dmft}(\%)$ : FT 11 & $\begin{array}{l}\text { Dmft (\%): PT } 7 \\
\text { LBW: } 44\end{array}$ & $\begin{array}{l}0.313 \\
\leq 0.001\end{array}$ \\
\hline Sridexia, 2018 & $\begin{array}{l}\text { ECC (\%): FT } 45.2 \\
\text { NBW } 49.9\end{array}$ & $\begin{array}{l}\text { ECC: PT } 58.9 \\
\text { LBW } 50.6\end{array}$ & $\begin{array}{l}0.001 \\
0.45\end{array}$ \\
\hline Soares, 2019 & $\begin{array}{l}\text { Deft (\%): AGA } 6 \\
\text { NBW } 6\end{array}$ & $\begin{array}{l}\text { Deft: SGA } 6 \\
\text { LBW } 6\end{array}$ & $\begin{array}{l}0.557 \\
0.209 \\
\end{array}$ \\
\hline Boustedt, 2020 & $\begin{array}{l}\text { ECC (\%): FT 14.9, } \\
\text { AGA } 14,5\end{array}$ & $\begin{array}{l}\text { ECC (\%): PT 61,5 } \\
\text { SGA 33,3 }\end{array}$ & \begin{tabular}{|l|}
$<0.001$ \\
0.036
\end{tabular} \\
\hline
\end{tabular}

full set of primary dentitions, especially considering that a lot of preterm children have developmental issues. Moreover, older children were exposed to risk factors for a longer period of time and had a higher chance to develop more carious lesions. Secondly, a socioeconomic status plays a vital role in the prevalence of dental caries development [18]. A study in Brazil reported that children born in low-income families have a $57 \%$ higher caries incidence than those in higher income families [8]. Some of the studies, however, ignored it and blended the different groups of patients altogether [8-10, 13]. Also, background information, such as maternal health, oral hygiene habits, nutrition, sugar consumption, in most of the studies was collected through self-reported questionnaires [8-13, 15-17]. Therefore, the results should be interpreted with more caution. Furthermore, the studies involved in this systematic review would have shown more accurate results if the studies reported the children were subgrouped. In the present systematic review, it was difficult to combine data and perform a meta-analysis due to the heterogeneity of the studies and a limited number of studies which used the same outcome indexes.

Lastly, we need to keep in mind that the relationship of caries and adverse birth outcomes has a lot of contributing factors. According to a study of Targino et al., preterm birth is linked to several 
enamel defects, which lead to a development of caries [19]. Also, children with adverse birth outcomes tend to have a reduced immune response and an impaired immune competence [20]. This, in turn, might make them prone to an early acquisition of S.Mutans [21]. A study in Sweden by Brogardh-Roth et al. found that preterm children in their preschool years (3- to 5-year-olds) display a higher prevalence of Dental Behavioural Management Problems at dental examinations and treatments [22]. At the age of 6, however, no significant differences between the groups were found, which means that DBMP are temporary and possibly more common in younger, less mature children [22]. Furthermore, preterm children are said to receive nightly bottle feeding more frequently compared to the full-term children, so that they could weigh as healthy-born average babies [23, 24]. This kind of behaviour promotes the development of early childhood caries. Therefore, in order to single out adverse birth outcomes as a definite risk factor, a study should be designed, which would state as many confounding factors as possible, in order to reduce a risk of bias.

\section{Conclusion}

In conclusion, the found scientific evidence demonstrated that children with adverse birth outcomes such as being small for gestational age, preterm or low birth weight, are more likely to experience caries than healthy children. However, due to heterogeneity of the included studies a meta-analysis could not have been performed, therefore leaving the level of the evidence moderately lower. In addition, confounding factors such as weak immune system, bottle feeding at nighttime, enamel defects, etc. should be taken into consideration in future studies to increase reliability of the results.

\section{References}

1. Liu L, Oza S, Hogan D, Chu Y, Perin J, Zhu J, et al. Global, regional, and national causes of under-5 mortality in 2000-15: an updated systematic analysis with implications for the sustainable development goals. Lancet 2016;388(10063):3027-3035. https://doi.org/10.1016/S0140-6736(16)31593-8

2. Black RE. Global prevalence of small for gestational age births. In Nestle Nutr Inst Workshop Ser 2015;81: 1-7. https://doi.org/10.1159/000365790

3. Behrman RE, Butler AS. Preterm birth. Causes, consequences, and prevention. National Academies Press. 2007

4. Soleimani F, Zaheri F, Abdi F. Long-term neurodevelopmental outcomes after preterm birth. In Iranian Red Crescent Medical J 2014; 16 (6),e17965.

https://doi.org/10.5812/ircmj. 17965

5. Jacobsen PE, Haubek D, Henriksen TB, Østergaard JR, Poulsen S. Developmental enamel defects in children born preterm: a sys- tematic review. In European J Oral Sciences 2014;122(1):7-14. https://doi.org/10.1111/eos.12094

6. Caufield PW, Li Y, Bromage TG. Hypoplasia-associated severe early childhood caries--a proposed definition. J Dental Research 2012;91(6):544-550.

https://doi.org/10.1177/0022034512444929

7. Costa FS, Silveira ER, Pinto GS, Nascimento GG, Thomson WM, Demarco Flávio F. Developmental defects of enamel and dental caries in the primary dentition: a systematic review and meta-analysis. J Dentistry 2017;60: 1-7.

https://doi.org/10.1016/j.jdent.2017.03.006

8. dos Santos Junior VE, Sousa RMB, Oliveira MC, Caldas Junior AF, Rosenblatt A. Early childhood caries and its relationship with perinatal, socioeconomic and nutritional risks: a crosssectional study. BMC Oral Health 2014;14:47.

https://doi.org/10.1186/1472-6831-14-47

9. Rajshekar SA, Laxminarayan N. Comparison of primary dentition caries experience in pre-term low birth-weight and full-term normal birth-weight children aged one to six years. J Indian Society Pedodontics Preventive Dentistry 2011;29 (2):128-134.

https://doi.org/10.4103/0970-4388.84685

10. Nirunsittirat A, Pitiphat W, McKinney CM, DeRouen TA, Chansamak N, Angwaravong O, et al. Adverse birth outcomes and childhood caries: a cohort study. Community Dentistry Oral Epidemiology 2016;44 (3):239-247.

https://doi.org/10.1111/cdoe.12211

11. Schüler IM, Haberstroh S, Dawczynski K, Lehmann T, Heinrich-Weltzien R. Dental caries and developmental defects of enamel in the primary dentition of preterm infants: case-control observational study. Caries Research 2018;52 (1-2):22-31. https://doi.org/10.1159/000480124

12. Bernabé E, MacRitchie H, Longbottom C, Pitts NB, Sabbah W. Birth weight, breastfeeding, maternal smoking and caries trajectories. J Dental Research 2017;96 (2):171-178.

https://doi.org/10.1177/0022034516678181

13. Masumo R, Birungi N, Bårdsen A, Fadnes LT, Astrøm AN. Impact of low birthweight on early childhood caries in 6-36 months old infants in Uganda: a cross-sectional study. Acta Odontologica Scandinavica 2014;72(4):312-320.

https://doi.org/10.3109/00016357.2014.880189

14. Nelson S, Albert JM, Geng C, Curtan S, Lang K, Miadich S, et al. Increased enamel hypoplasia and very low birthweight infants. J Dental Research 2013;92(9):788-794.

https://doi.org/10.1177/0022034513497751

15. Soares FC, Dahllöf G, Hjern A, Julihn A. Adverse birth outcomes and the risk of dental caries at age 3 years. International J Paediatric Dentistry 2020;30(4):445-450.

https://doi.org/10.1111/ipd.12617

16. Boustedt K, Roswall J, Kjellberg E, Twetman S, Dahlgren J. A prospective study of perinatal and metabolic risk factors for 
early childhood caries. Acta Paediatrica (Oslo, Norway 1992) 2020;109(11):2356-2361. https://doi.org/10.1111/apa.15231

17. Sridevi T, Pranoti S, Anand S, Umesh W, Sachin G. Factors associated with early childhood caries among 3 to 6 year old children in India: a case control study. J Neonatal-Perinatal Medicine 2018;11(1):45-50. https://doi.org/10.3233/NPM-181723

18. Gokhale N, Nuvvula S. Influence of socioeconomic and working status of the parents on the incidence of their children's dental caries. J Natural Science, Biology, Medicine 2016;7(2):127-129. https://doi.org/10.4103/0976-9668.184697

19. Targino AGR, Rosenblatt A, Oliveira AF, Chaves AMB, Santos VE. The relationship of enamel defects and caries: a cohort study. Oral Diseases 2011;17(4):420-426. https://doi.org/10.1111/j.1601-0825.2010.01770.x

20. Chandra RK. Nutrition and the immune system from birth to old age. European J Clinical Nutrition 2002;56(Suppl 3):S73-6. https://doi.org/10.1038/sj.ejen.1601492

21. Law V, Seow WK, Townsend G. Factors influencing oral colonization of mutans streptococci in young children. Australian Dental J 2007;52(2):93-100. https://doi.org/10.1111/j.1834-7819.2007.tb00471.x

22. Brogårdh-Roth S, Stjernqvist K, Matsson L. Dental behavioural management problems and dental caries prevalence in 3- to 6-year-old Swedish children born preterm. International J Paediatric Dentistry 2008;18(5):341-347. https://doi.org/10.1111/j.1365-263X.2007.00884.x

23. Oliveira AFB, Chaves AMB, Rosenblatt A. The influence of enamel defects on the development of early childhood caries in a population with low socioeconomic status: a longitudinal study. Caries Research 2006:40(4):296-302.

https://doi.org/10.1159/000093188

24. Ferrini FRD, Marba STM, Gavião MBD. Oral conditions in very low and extremely low birth weight children. J Dentistry Children (Chicago, Ill.) 2008;75 (3):235-242.

\section{ANKSTYVOJO VAIKŲ DANTŲ ĖDUONIES IR NEPALANKIOS NĖŠTUMO BAIGTIES SĄSAJOS}

A. Varoneckas, K. Jasinskaitė, A. Varašiūtė

Raktažodžiai: priešlaikinis gimimas, mažas gimimo svoris, ankstyvasis vaikų èduonis, neišnešioti kūdikiai, mažas gestacinio amžiaus atžvilgiu, nepalankios neeštumo baigtys, perinatalinès komplikacijos, dantų ėduonis.

Santrauka

Tikslas - ịvertinti nepalankios nèštumo baigties ryši su ankstyvuoju vaikų dantų èduonimi.

Metodai. Nuo $2020 \mathrm{~m}$. vasario mènesio du tyrèjai atliko internetinę paiešką skirtingose elektroninėse duomenų bazėse. ROBINS-I buvo naudojamas ịvertinti straipsnių, ịtrauktų ị šią sisteminę apžvalgą, bendrą kokybę ir šališkumo riziką.

Rezultatai. Po pirminès paieškos, atliktos elektroninèse duomenų bazėse, atrinkti 1376 straipsniai. Autoriai atrinko 10 straipsnių, kuriuose aprašomi vaikų su pieniniu sąkandžiu, kurių amžius nuo 0,5 iki 6 metų, dantų èduonies paplitimo tyrimai. Visi atrinkti retrospektyviniai, kohortiniai, atvejo ir kontrolès bei vienmomenčiai skerspjūvio tyrimai buvo publikuoti nuo 2010 iki 2020 metų.

Išvada. Rasti moksliniai duomenys parodè, jog dantų èduonis dažniau pasireiškia gimusiems esant nepalankiai nèštumo baigčiai, nei sveikiems vaikams.

Adresas susirašinèti: abudzio@yahoo.com

Gauta 2021-05-05 